\title{
The Growth of Rabbitpox Virus in Tissue Culture
}

\author{
By G. APPLEYARD AND J. C. N. WESTWOOD \\ Microbiological Research Establishment, Porton, Wiltshire
}

(Received 5 June 1964)

\begin{abstract}
SUMMARY
The growth of rabbitpox virus has been studied in monolayer cultures of HeLa (ERK) cells. At $36^{\circ}$, virus was adsorbed to cells at about one-tenth of the theoretical collision rate. The adsorbed virus penetrated the cells exponentially, the time for half penetration being about $1 \mathrm{hr}$. New infective virus began to appear at $5 \mathrm{hr}$, and the final yield at $24 \mathrm{hr}$ was about $100 \mathrm{pfu}$ per cell. The synthesis of viral antigen began $1 \frac{1}{2} \mathrm{hr}$ after infection of the cultures; this was $1 \mathrm{hr}$ before the earliest appearance of viral DNA. When virus growth was complete, over 20 separate antigens could sometimes be detected in extracts of infected cells. The yield of antigens was not reduced when virus multiplication was completely inhibited by bromodeoxyuridine. It was concluded that the synthesis of viral antigens was directed by the DNA of the infecting virus, and not by the DNA formed during virus growth.
\end{abstract}

\section{INTRODUCTION}

The final maturation of pox viruses is known to be preceded by the synthesis of both viral antigen (Cairns, 1960; Loh \& Riggs, 1961; Appleyard, Westwood \& Zwartouw, 1962; Shatkin, 1963) and viral DNA (Cairns, 1960; Magee, Sheek \& Burrous, 1960; Kato, Kameyama \& Kamahora, 1960; Salzman, 1960; Loh \& Riggs, 1961; Easterbrook \& Davern, 1963; Shatkin, 1963). It is uncertain, however, whether these two substances appear simultaneously in the infected cells, or whether one is formed before the other. This question becomes important when considering the possible functions of viral antigen and DNA in the growth of pox viruses.

In the present study of the growth of rabbitpox virus, we paid particular attention to the times of first development of viral antigen, viral DNA and infective virus. The adsorption and penetration of virus, being essential preliminaries to the later synthetic processes, were also investigated.

\section{METHODS}

Viruses. Rabbitpox virus was the Utrecht strain, which had been passed about 25 times in HeLa (ERK) cells. Stock virus was prepared by ultrasonic disruption of infected cells in maintenance medium, and had a titre of about $10^{8}$ plaqueforming units (p.f.u.)/ml.

Cell cultures. The ERK 1 cell line (Westwood, Macpherson \& Titmuss, 1957) was used. There is antigenic evidence that this probably arose from a contaminating HeLa cell (Coombs, Daniel, Gurner \& Kelus, 1961). It will therefore be referred to in this and future publications as the HeLa (ERK) cell line.

The medium for cell growth consisted of Earle saline with the addition of $10 \%(v / v)$ 
calf serum, $5 \%(\mathrm{v} / \mathrm{v})$ tryptic meat broth, $0.5 \%(\mathrm{v} / \mathrm{v})$ yeast extract, 100 units penicillin $/ \mathrm{ml}$. and $100 \mu \mathrm{g}$. streptomycin $/ \mathrm{ml}$. It was equilibrated with $5 \% \mathrm{CO}_{2}$ in air. For most experiments, cell cultures were grown in $8 \mathrm{~cm}$. Carrel flasks; an inoculum of $7 \times 10^{6}$ cells, when incubated overnight, yielded a confluent monolayer containing almost exactly the original number of cells.

Infection of cultures. In most experiments, cells were infected with a high virus multiplicity in order to obtain a one-step growth curve. Monolayer cultures in Carrel flasks were incubated for $1 \mathrm{hr}$ at $36^{\circ}$ with $2 \mathrm{ml}$. virus suspension of titre $10^{8}$ p.f.u./ml. They were then washed three times with phosphate buffered saline, $10 \mathrm{ml}$. medium containing $5 \%$ instead of $10 \%(\mathrm{v} / \mathrm{v})$ calf serum ('maintenance medium') was added, and incubation was continued at $36^{\circ}$. From experiments on the rate of virus adsorption, it was calculated that the amount of virus adsorbed should be about 7 p.f.u./cell and therefore almost all cells should be infected. This was confirmed by the observation that well over $90 \%$ of the cells underwent a rapid cytopathic effect and also developed inclusions of viral antigen. Virus growth times were measured from the beginning of the adsorption period.

Virus titration. Infected cultures were harvested by scraping the cells from the glass, and disrupting them when in suspension by exposure for $2 \mathrm{~min}$. to ultrasonic vibration $(40 \mathrm{kcyc}$. $/ \mathrm{sec}$. at $500 \mathrm{~W}$. produced by an ultrasonic transducer, type no. 1160, Dawe Instruments Ltd., London).

Virus was titrated as plaque-forming units (p.f.u.) in HeLa (ERK) cells. The disrupted cell suspensions were diluted in medium that contained $0.05 \%(\mathrm{w} / \mathrm{v})$ galactose in place of glucose and lacked both calf serum and bicarbonate. Threeml. volumes of the appropriate dilutions were added to HeLa (ERK) monolayers in $7 \mathrm{~cm}$. Petri dishes, and incubated in air at $36^{\circ}$ for $16 \mathrm{hr}$. After this adsorption period, the inoculum was replaced by $10 \mathrm{ml}$. maintenance medium containing a 1/1000 dilution of rabbitpox antiserum. The function of the antiserum was to prevent the formation of secondary plaques without interfering with the development of plaques from the primarily infected cells. The cultures were incubated at $36^{\circ}$ in air $+5 \% \mathrm{CO}_{2}$ for 2 more days, and the plaques counted after staining with $0.04 \%$ $(w / v)$ crystal violet. This titration method was $1 \cdot 5-6$ times as sensitive as the pock technique (Westwood, Phipps \& Boulter, 1957) when tested with a variety of preparations of rabbitpox and vaccinia viruses. The plaque count was proportional to the virus concentration up to at least 200 plaques per culture, and the counts in replicate cultures showed a Poissonian distribution.

Staining of infected cells. Viral antigen: infected coverslip cultures were fixed in acetone at $-20^{\circ}$, and stained with fluorescein-conjugated rabbitpox antiserum that had been adsorbed with acetone-dried human liver. The stained cells were examined microscopically by dark-ground ultraviolet illumination.

Viral DNA: cultures on coverslips were fixed in ethanol at room temperature, stained with a solution of acridine orange in methanol (Randles, 1960), and examined by dark-ground ultraviolet illumination.

Immunodiffusion tests. The infected monolayers were scraped from the glass into the culture medium, concentrated by centrifugation to $4 \times 10^{7}$ cells $/ \mathrm{ml}$. in phosphatebuffered saline, and disrupted by $5 \mathrm{~min}$. exposure to ultrasonic vibration. The cell extracts produced in this way were examined for soluble precipitating antigens by micro-immunodiffusion (Crowle, 1958) against rabbitpox antiserum. 
Antiserum. Rabbitpox antiserum was used for immunodiffusion tests, for neutralizing extracellular virus in some experiments, and for preventing the secondary spread of virus in plaque titrations. It was obtained from rabbits that had recovered from a rabbitpox infection and were then hyperimmunized by several intravenous injections of an extract of rabbit testes containing $5 \times 10^{8}$ p.f.u. $/ \mathrm{ml}$. of rabbitpox virus. The neutralizing antibody titre of this serum against vaccinia (Boulter, 1957) was 500,000 .

\section{RESULTS}

\section{Adsorption and penetration of virus}

The adsorption and penetration of vaccinia virus during the infection of cell monolayers have been studied by Postlethwaite (1960) and Allison \& Valentine (1960). Our results were in general agreement, and so will be summarized only briefly.

Virus adsorption was measured by incubating cell monolayers with dilute inocula, the adsorbed virus being titrated directly by the formation of plaques on the test cultures. During the first hour at $36^{\circ}$, the amount of virus adsorbed per $\mathrm{cm}^{2}$ of monolayer was equivalent to that contained in $0.010 \mathrm{ml}$. inoculum; for a given virus concentration, the initial rate of adsorption was not affected by the volume of inoculum. Application of the formula of Valentine \& Allison (1959) to this result indicates that virus was adsorbing to cells at about $10 \%$ of the theoretical collision rate. At $23^{\circ}$ and $4^{\circ}$, virus adsorption was slower and, in contrast to that at $36^{\circ}$, it was incomplete.

Virus penetration was studied by investigating the rate at which virus, previously adsorbed to monolayers at $4^{\circ}$, became insusceptible to the neutralizing action of antiserum. At $36^{\circ}$, virus disappeared from the cell surface exponentially, the time for penetration of half the virus being $1 \mathrm{hr}$. At $21^{\circ}$, the rate of penetration was only about $5 \%$ of that at $36^{\circ}$, and at $4^{\circ}$ no virus entered the cells.

\section{Virus growth curve}

In a one-step growth curve, new infective virus was first detected at $5 \mathrm{hr}$. The virus titre then continued to rise, and the final yield at $24 \mathrm{hr}$ was about 100 p.f.u./ cell. Over $90 \%$ of the virus remained intracellular.

\section{Formation of viral $D N A$}

The synthesis of viral nucleic acid was studied by two independent methods: infected cells were stained with acridine orange to detect the presence of inclusions of DNA in the cytoplasm; and the synthesis of DNA that became incorporated into infective virus was investigated by showing how virus growth was inhibited by bromodeoxyuridine and how this inhibition was neutralized with thymidine.

Acridine orange staining. A series of cell cultures on coverslips was infected by incubation for $1 \mathrm{hr}$ at $36^{\circ}$ with a virus suspension containing $10^{7}$ p.f.u. $/ \mathrm{ml}$. Excess virus was removed by washing, and incubation was continued in maintenance medium at $36^{\circ}$. At intervals, measured from the beginning of the virus adsorption period, sample cultures were stained with acridine orange and examined microscopically under ultraviolet illumination. Cytoplasmic foci of DNA were first visible in a few cells at $3 \mathrm{hr}$, and by $8 \mathrm{hr}$ about half the cells were seen to be infected. 
The foci in their earliest stage of development were small, well defined, roughly circular and usually multiple. Later, at about $6 \mathrm{hr}$, many of the foci were beginning to spread irregularly through the cytoplasm. By $24 \mathrm{hr}$ after infection, the cells had formed syncytial masses which contained large amounts of diffuse DNA. In some cells at the later stages of infection, newly formed virus particles could be seen as minute greenish dots; it was apparent that, even at $24 \mathrm{hr}$, only a small proportion of the total cytoplasmic DNA was incorporated into these particles. Plate 1, figs. 1 and 2, illustrate DNA foci that developed after this fairly low multiplicity of infection.

Table 1. Effect of thymidine on inhibition of the groroth of rabbitpox virus by bromodeoxyuridine (BDU)

\begin{tabular}{|c|c|c|c|c|}
\hline \multirow{2}{*}{$\begin{array}{c}\text { BDU } \\
\text { concentration } \\
(\mu \mathrm{g} . / \mathrm{ml} .)\end{array}$} & \multicolumn{4}{|c|}{ Thymidine concentration $(\mu \mathrm{g} . / \mathrm{ml}$.) } \\
\hline & 0 & $\begin{array}{c}25 \\
\text { Virus }\end{array}$ & $\begin{array}{l}100 \\
\text {.f.u./ }\end{array}$ & 400 \\
\hline 0 & 46 & - & - & 60 \\
\hline 18 & 0.28 & $6 \cdot 0$ & 41 & 53 \\
\hline 54 & 0.20 & 0.33 & $9 \cdot 4$ & 27 \\
\hline 162 & 0.26 & 0.26 & 0.3 & \\
\hline
\end{tabular}

When cells were infected with a virus suspension containing $10^{8}$ p.f.u./ml., the inoculum used to produce a one-step growth curve, well over $90 \%$ of the cells became infected. Multiple small foci of DNA could be seen in occasional cells as early as $2 \frac{1}{2} \mathrm{hr}$, and by $3 \mathrm{hr}$ about $50 \%$ of the cells contained inclusions.

Bromodeoxyuridine. A concentration of $20 \mu \mathrm{g}$. bromodeoxyuridine (BDU)/ml. completely suppressed the formation of infective rabbitpox virus. The action of the drug was competitively inhibited by thymidine (Table 1). Staining of infected cultures with acridine orange showed that apparently typical inclusions of DNA were formed when virus growth was inhibited by BDU. These observations are consistent with the conclusion of Easterbrook \& Davern (1963) that BDU competes with thymidine for incorporation into viral DNA with the result that the DNA formed in its presence gives rise to non-infective virus.

The time of viral DNA synthesis was measured by observing the effect on the final virus yield either of adding BDU to cultures at various times after infection or of annulling its action at these times. Three series of cell cultures in Carrel flasks were infected as for a one-step growth curve. Cultures from one series were harvested at intervals and titrated to show the course of infective virus production (Fig. 1, curve $\mathrm{A}$ ). To a second series, $20 \mu \mathrm{g}$. $\mathrm{BDU} / \mathrm{ml}$. was added at various times, and the cultures were titrated for virus after incubation for $24 \mathrm{hr}$ (Fig. 1, curve B). The third series of cultures contained $20 \mu \mathrm{g}$. BDU $/ \mathrm{ml}$. from the beginning of incubation, but $400 \mu \mathrm{g}$. thymidine $/ \mathrm{ml}$. was added at various times after infection to annul the action of the drug; these cultures also were incubated for the full $24 \mathrm{hr}$ before titrating for virus (Fig. 1, curve C). Curve B represents the viral DNA formed before the addition of BDU at the times shown, and curve $\mathrm{C}$ the DNA formed after these times. The two curves are mirror images of one another. They indicate that the synthesis of DNA began shortly before $3 \mathrm{hr}$, was $50 \%$ complete by about $4 \frac{1}{2} \mathrm{hr}$, and over $90 \%$ complete by $8 \mathrm{hr}$. 
Similar experiments in which BDU was added to infected cultures at only $\frac{1}{2} \mathrm{hr}$ intervals, in order to determine more precisely the earliest time of DNA synthesis, showed that virus began to escape from inhibition by BDU at either $2 \frac{1}{2} \mathrm{hr}$ or $3 \mathrm{hr}$; when added only $2 \mathrm{hr}$ after infection, BDU was completely effective in suppressing virus multiplication. Viral DNA synthesis therefore began at about $2 \frac{1}{2} \mathrm{hr}$. This conclusion agrees well with that drawn from experiments in which infected cells were examined directly for DNA by staining with acridine orange.

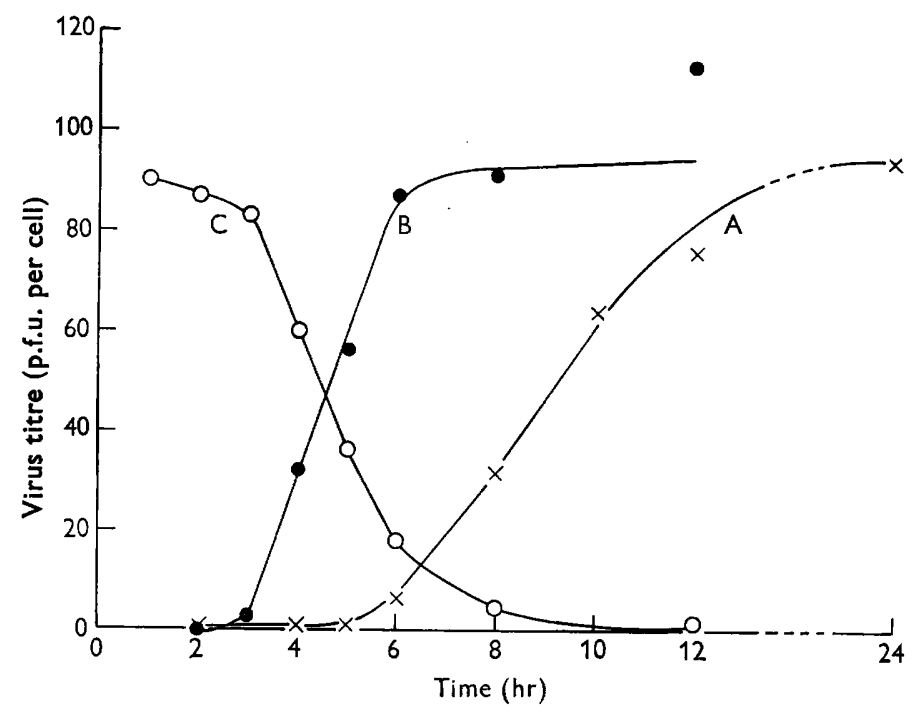

Fig. 1. Formation of viral DNA during one-step virus growth curve. $\times$, Virus content of cultures; 9 , virus yield at $24 \mathrm{hr}$ after addition of BDU at times shown; $O$, virus yield at $24 \mathrm{hr}$ after annulment of action of BDU at times shown.

\section{Formation of viral antigen}

The development of viral antigen, like that of viral DNA, was followed by two methods. The infected cells were stained with fluorescein-conjugated antibody; and cell extracts were examined for soluble antigens by immunodiffusion.

Fluorescent antibody staining. A series of cell cultures on coverslips was infected by exposure for $1 \mathrm{hr}$ at $4^{\circ}$ to partially purified rabbitpox virus at concentrations of $10^{6}, 10^{7}$ or $10^{8}$ p.f.u./ml. Unadsorbed virus was removed by washing and the cultures transferred to maintenance medium at $36^{\circ}$. At intervals, timed from the beginning of incubation at $36^{\circ}$, sample cultures were stained with fluorescein-conjugated rabbitpox antiserum and examined under ultraviolet illumination. Foci of viral antigen were confined to the cytoplasm. They were at first small and well-defined; later they increased in size, became irregular and fragmented, and eventually spread throughout the cytoplasm (Pl. 1, figs. 3-6). Virus particles could be seen in some cells at $8 \mathrm{hr}$, and by $24 \mathrm{hr}$ they were present in most infected cells. It was obvious, as was found with viral DNA, that most of the antigen did not become incorporated into these particles. Counts were made on each coverslip of $(a)$ the proportion of cells that contained viral antigen, and $(b)$ the number of antigen foci in the individual infected cells (Fig. 2). After infection by the most concentrated inoculum, $22 \%$ of 
the cells contained antigen as early as $2 \mathrm{hr}$, though the less heavily infected cultures did not begin to develop antigen until $3 \mathrm{hr}$ or $4 \mathrm{hr}$. At the stage of growth when only a small proportion of cells contained antigen, the cells that did so showed more foci on an average than those that developed antigen later. Moreover, the foci were roughly the same size in any one cell. These observations support the conclusions of Cairns (1960) that in an individual cell all foci of virus synthesis begin development at the same time, and that the more heavily infected a cell the earlier is the growth of virus.

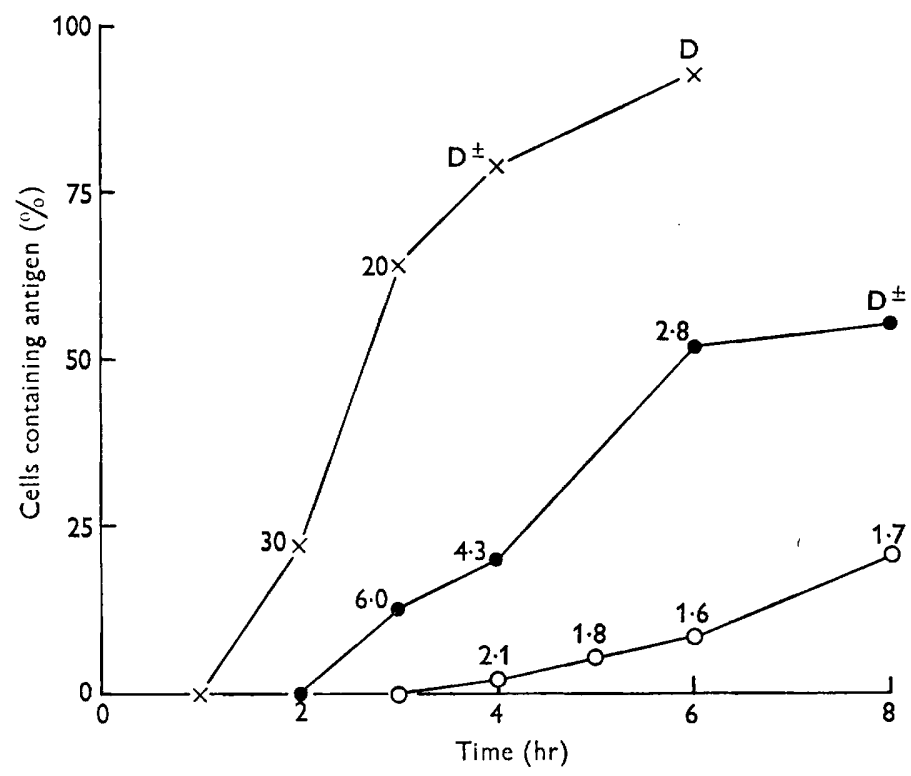

Fig. 2. Formation of inclusions of viralantigen after infection of cell monolayers with three different virus multiplicities. Titres of virus inocula: $\times, 10^{8}$ p.f.u. $/ \mathrm{ml}$; $Q, 10^{7}$ p.f.u. $/ \mathrm{ml}$; $0,10^{6}$ p.f.u. $/ \mathrm{ml}$. Figures on curves indicate mean number of inclusions per infected cell; $\mathrm{D} \pm$, diffuse antigen in many cells; $\mathrm{D}$, diffuse antigen in most cells.

Further analysis of the counts of antigen foci in infected cells revealed that they fell well outside the expected Poissonian distribution. This was shown particularly well by the pooled results of five experiments in which cultures were infected by rabbitpox virus of titre $10^{7} \mathrm{p} . f . u . / \mathrm{ml}$. At $8 \mathrm{hr}$, when the number of antigen-containing cells had reached a maximum, $437 / 750$ cells $(58 \%)$ were seen to be infected. Assuming random distribution of the infecting virus and equal susceptibility of all cells, this would correspond to a mean of 0.87 infective particles per cell. The expected distribution of the numbers of infective particles per cell is shown in Fig. 3, curve A. Only about $0.2 \%$ of the cells should have received more than 4 infective units, and therefore only this proportion of cells would be expected to contain more than 4 inclusions. It was not possible to count the inclusions in cells at $8 \mathrm{hr}$ owing to their diffuse nature at this stage of growth. Counts could however be made in the cultures stained at $5 \mathrm{hr}$ or $6 \mathrm{hr}$, at which time $217 / 451(48 \%)$ of cell $_{\mathrm{S}}$ showed antigen. It was found that as many as $42 / 451(9 \cdot 3 \%)$ of the cells contained 5 or more foci (Fig. 3, curve B), and this figure excludes 8 cells in which the foci 
were uncountable due to spreading. Examination of cultures stained only 3 or $4 \mathrm{hr}$ after infection showed that $224 / 1090(21 \%)$ of cells contained antigen; $94 / 1090(8.5 \%)$ contained 5 or more foci, and 8 of these had from 10 to 14 foci (Fig. 3, curve C).

The above results could not be accounted for by variations in the number of virus particles infecting the individual cells. When cultures that had not been fixed with acetone were stained with fluorescein-conjugated antiserum, it was possible to count the virus particles adsorbed to the surface of the cells. Under the conditions already described, 143 cells adsorbed a mean of $10 \cdot 1$ particles per cell. The distribu-

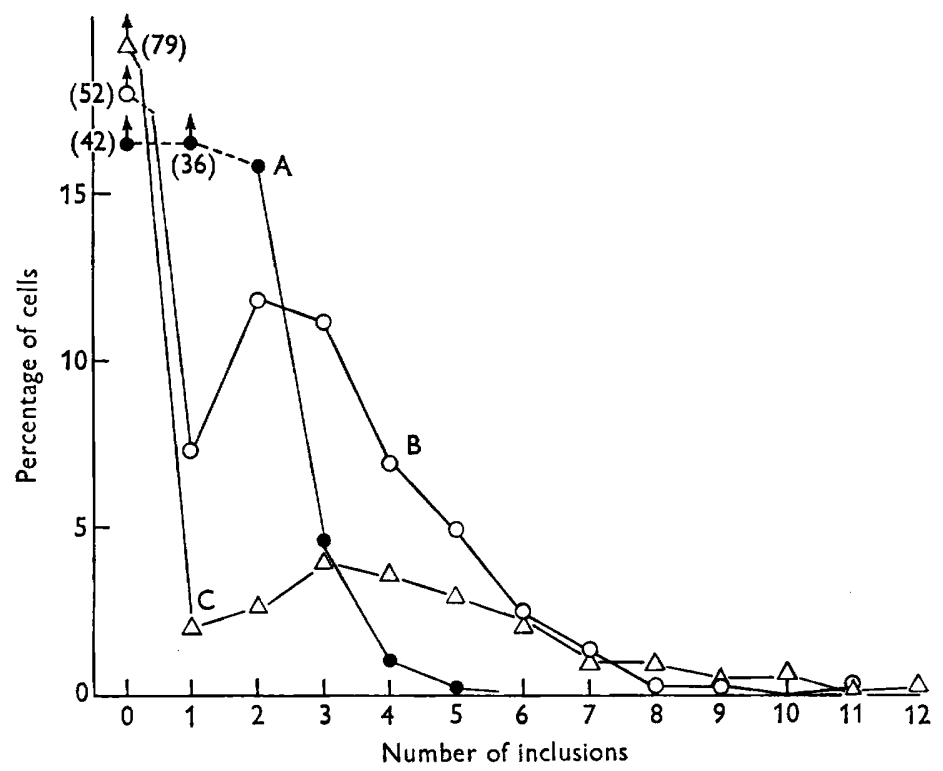

Fig. 3. Numbers of inclusions of viral antigen seen in individual cells after infection of cultures with a virus inoculum of $10^{7}$ p.f.u. $/ \mathrm{ml}$. O, Theoretical counts; $O$, counts made $5 \mathrm{hr}$ and $6 \mathrm{hr}$ after infection; $\Delta$, counts made $3 \mathrm{hr}$ and $4 \mathrm{hr}$ after infection.

tion of counts fell only slightly outside the Poissonian expectation, and only 2 cells adsorbed more than 20 particles. These counts therefore confirmed the assumption of a random distribution of infecting virus. They also gave a particle:infectivity ratio of $10 \cdot 1: 0 \cdot 87$ or $11 \cdot 6: 1$ for this preparation of rabbitpox virus. Another possible explanation for the distribution of counts shown in Fig. 3 would be the existence of a great variation in susceptibility of the cells to virus infection. But it is difficult to account on this basis for the unexpectedly small number of cells that developed only a single antigen focus. A more likely explanation is that some non-infective particles became 'reactivated' (Fenner, Holmes, Joklik \& Woodroofe, 1959) in cells that also received fully infective virus. Since the maximum number of inclusions per cell was about 10 and the maximum number of adsorbed particles about 20 , it would seem on this hypothesis that up to $50 \%$ of the virus particles might be reactivable.

Immunodiffusion analysis. Although immunodiffusion could not detect insoluble viral antigens, the method was able to reveal the great complexity of the mixture of soluble antigens. Extracts of cells harvested $24 \mathrm{hr}$ after infection sometimes produced over 20 countable lines with rabbitpox antiserum. In order to follow the 
course of soluble antigen synthesis, a series of cell cultures in Carrel flasks was infected as for a one-step virus growth curve. At intervals, the cells from sample cultures were concentrated by centrifugation, disrupted by ultrasonic vibration, and examined by immunodiffusion against rabbitpox antiserum. Some antigens were present in the cell extract made at $2 \mathrm{hr}$, more had appeared by $4 \mathrm{hr}$ and almost the full $24 \mathrm{hr}$ yield of antigens was attained by $6 \mathrm{hr}$. The examination of cell extracts harvested at $\frac{1}{2} \mathrm{hr}$ intervals during the early stages of virus growth showed that some antigens were formed only $1 \frac{1}{2} \mathrm{hr}$ after infection, and a trace of antigen could sometimes be detected $\frac{1}{2} \mathrm{hr}$ earlier than this. By $2 \mathrm{hr}$ after infection, when DNA synthesis had not yet begun, the cells usually contained between 5 and 10 viral antigens.

\section{Relationship between viral DNA synthesis and the formation of viral antigens}

The observation that the synthesis of viral antigens began at least $1 \mathrm{hr}$ before that of viral DNA suggested that antigen synthesis was not directed by the newly formed viral DNA. This conclusion was confirmed by studying the effect of BDU on the production of viral antigens.

Cell cultures on coverslips, infected by adsorption of virus of titre $10^{8} \mathrm{p} . \mathrm{f} . \mathrm{u} . / \mathrm{ml}$. for $1 \mathrm{hr}$ at $36^{\circ}$, were incubated in maintenance medium with or without $20 \mu \mathrm{g}$. BDU $/ \mathrm{ml}$. The yield of virus at $24 \mathrm{hr}$ was 120 p.f.u./cell in the control cultures and 0.9 p.f.u./ cell in the inhibited cultures. Sample cultures were examined for intracellular antigen by staining with fluorescein-conjugated rabbitpox antiserum at $5 \mathrm{hr}, 7 \mathrm{hr}$ and $24 \mathrm{hr}$. Viral antigen developed equally well in the two groups of cultures, the foci in both being at first multiple and discrete and later becoming fragmented and diffused throughout the cytoplasm.

As an alternative test, cell cultures in Carrel flasks were infected as above and then incubated for $24 \mathrm{hr}$ in normal maintenance medium or in medium containing $20 \mu \mathrm{g}$. or $40 \mu \mathrm{g}$. BDU $/ \mathrm{ml}$. The virus yield in the control cultures was 91 p.f.u./cell and in the inhibited cultures 0.4 and 0.3 p.f.u./cell. The concentrated cell extracts, harvested at $24 \mathrm{hr}$, were examined for soluble antigens by immunodiffusion against rabbitpox antiserum. So far as could be seen, BDU did not suppress the formation of any antigen. On the contrary, in this and in most similar experiments, the yield of antigen was rather greater from the inhibited cultures than from the controls.

\section{DISCUSSION}

The earliest time of synthesis of pox-virus DNA has been accurately measured, using the inhibitors fluorodeoxyuridine or bromodeoxyuridine, by Salzman (1960), Salzman, Shatkin \& Sebring (1963), and Easterbrook \& Davern (1963), who found that synthesis of DNA preceded that of infective virus by several hours. Our results with bromodeoxyuridine showed that the formation of rabbitpox virus DNA begins $2 \frac{1}{2} \mathrm{hr}$ after infection, about half-way through the eclipse phase of the growth cycle. The staining of infected cells with acridine orange confirmed this, and also showed that considerably more cytoplasmic DNA was formed than ever became incorporated into virus particles. It is not yet possible to say whether this unincorporated DNA possesses some separate function, or whether its synthesis is due 
merely to inefficiency of the repression mechanisms whose existence has recently been suggested by the work of McAuslan $(1963 a, b)$.

The synthesis of 'viral antigen' is a more complex process than that of DNA, since the infected cells produce a very large number of different antigens. Extracts of cells taken when virus growth was complete could produce twenty or more lines by immunodiffusion against rabbitpox antiserum, and there was no reason to suppose that each of these lines did not arise from a separate antigen. It would be expected that the various antigens would have different functions, and might therefore be formed at different stages of virus growth. There is already some indication of this from the work of Loh \& Riggs (1961), who found, by staining infected cells with specific fluorescein-conjugated antisera, that LS antigen was formed before NP antigen. The method of immunodiffusion now shows that the many soluble antigens of rabbitpox virus are synthesized at very different times in the growth cycle. Some appear early in the eclipse phase, whereas others are not present in detectable amounts until virus maturation has already begun. The times of synthesis of the various antigens may be one of the pieces of information that will lead eventually to an elucidation of their functions.

Previous workers who followed the formation of both viral DNA and viral antigen in the same system found that the two types of material appeared at about the same time (Cairns, 1960; Loh \& Riggs, 1961; Shatkin, 1963). In our system, some soluble viral antigens could be detected by immunodiffusion in cell extracts harvested only $1 \frac{1}{2} \mathrm{hr}$ after infection, and traces of antigen were sometimes present after only $1 \mathrm{hr}$. The synthesis of viral antigen therefore precedes that of viral DNA by at least $1 \mathrm{hr}$. The fact that antigen was not detected by staining with fluoresceinconjugated antibody until $2 \mathrm{hr}$ after infection might be explained by the inability of this method to detect very small foci of antigen. Alternatively, it is possible that the earliest antigen behaved differently from that formed later, by diffusing through the cytoplasm instead of remaining localized at its site of synthesis; if this were so the antigen would be difficult to detect by staining.

The synthesis of viral antigen might be directed either by the DNA of the originally infecting virus or by the DNA formed later during virus growth. The finding that many antigens were produced in cells before any DNA synthesis had occurred indicated that the formation of some antigens at least was independent of new DNA synthesis. Moreover, Easterbrook \& Davern (1963) and Shatkin (1963) have shown that some viral antigen was formed when viral DNA synthesis was interfered with by bromo- or fluorodeoxyuridine. The examination of our cell extracts by immunodiffusion indicated that bromodeoxyuridine, at a concentration sufficient to prevent all infective virus formation, did not inhibit the synthesis of any of the viral soluble antigens. It therefore seems likely that the antigens are formed solely under the influence of the DNA of the originally infecting virus, and that DNA formed subsequently plays no part in the process. On the other hand, the early antigens might themselves be essential for the synthesis of viral DNA. Some evidence on this subject will be presented later.

We wish to thank Miss H. J. Way for her expert technical assistance throughout this work. 


\section{REFERENCES}

Alrison, A. C. \& Valentine, R. C. (1960). Virus particle adsorption. III. Adsorption of viruses by cell monolayers and effects of some variables on adsorption. Biochim. biophys. Acta, 40, 400.

Appleyard, G., Westwood, J. C. N. \& Zwartouw, H. T. (1962). The toxic effect of rabbit-pox virus in tissue culture. Virology, 18, 159.

Boulter, E. A. (1957). The titration of vaccinial neutralizing antibody on chorio-allantoic membranes. J. Hyg., Camb. 55, 502.

Carrns, J. (1960). The initiation of vaccinia infection. Virology, 11, 603.

Coombs, R. R. A., Daniel, M. R., Gurner, B. W. \& Kelus, A. (1961). Species characterising antigens of ' $L$ ' and 'ERK' cells. Nature, Lond. 189, 503.

Crowle, A. J. (1958). A simplified micro double-diffusion agar precipitin technique. J. lab. clin. Med. 52, 784.

Easterbrook, K. B. \& Davern, C. I. (1963). The effect of 5-bromodeoxyuridine on the multiplication of vaccinia virus. Virology, $19,509$.

Fenner, F., Holmes, I. H., Joklrk, W. K. \& Woodroofe, G. M. (1959). Reactivation of heat-inactivated poxviruses: a general phenomenon which includes the fibromamyxoma virus transformation of Berry and Dedrick. Nature, Lond. 183, 1340.

Kato, S., Kameyama, S. \& Kamahora, J. (1960). Autoradiography with tritium-labelled thymidine of pox virus and human amnion cell system in tissue culture. Biken's J. 3, 135.

LoH, P. C. \& RigGs, J. L. (1961). Demonstration of the sequential development of vaccinial antigens and virus in infected cells: observations with cytochemical and differential fluorescent procedures. J. exp. Med. 114, 149.

McAuslan, B. R. (1963a). Control of induced thymidine kinase activity in the poxvirusinfected cell. Virology, 20, 162.

McAustan, B. R. (1963b). The induction and repression of thymidine kinase in the poxvirus-infected HeLa cell. Virology, 21, 383.

MAGEe, W. E., SheEk, M. R. \& Burrous, M. J. (1960). The synthesis of vaccinial deoxyribonucleic acid. Virology, 11, 296.

Postrethwaite, R. (1960). A plaque technique for the titration of vaccinia virus in chick embryo cells and some features of vaccinal infection in this system. Virology, 10, 466.

RANDLES, W. J. (1960). Induced fluorescence with acridine orange, after osmium fixation. Nature, Lond. 187, 964.

Salzman, N. P. (1960). The rate of formation of vaccinia deoxyribonucleic acid and vaccinia virus. Virology, $10,150$.

Salzman, N. P., Shatkin, A. J. \& Sebring, E. D. (1963). Viral protein and DNA synthesis in vaccinia virus-infected HeLa cell cultures. Virology, 19, 542.

Shatkin, A. J. (1963). The formation of vaccinia virus protein in the presence of 5-fluorodeoxyuridine. Virology, 20, 292.

VALENTINe, R. E. \& Alison, A. C. (1959). Virus particle adsorption. I. Theory of adsorption and experiments on the attachment of particles to non-biological surfaces. Biochim. biophys. Acta, 34, 10.

Westwood, J. C. N., Macpherson, I. A. \& Titmuss, D. H. J. (1957). Transformation of normal cells in tissue culture: its significance relative to malignancy and virus vaccine production. Brit. J. exp. Path. 38, 138.

Westwood, J. C. N., Phipps, P. H. \& Boulter, E. A. (1957). The titration of vaccinia virus on the chorioallantoic membrane of the developing chick embryo. J. Hyg., Camb. $55,123$. 

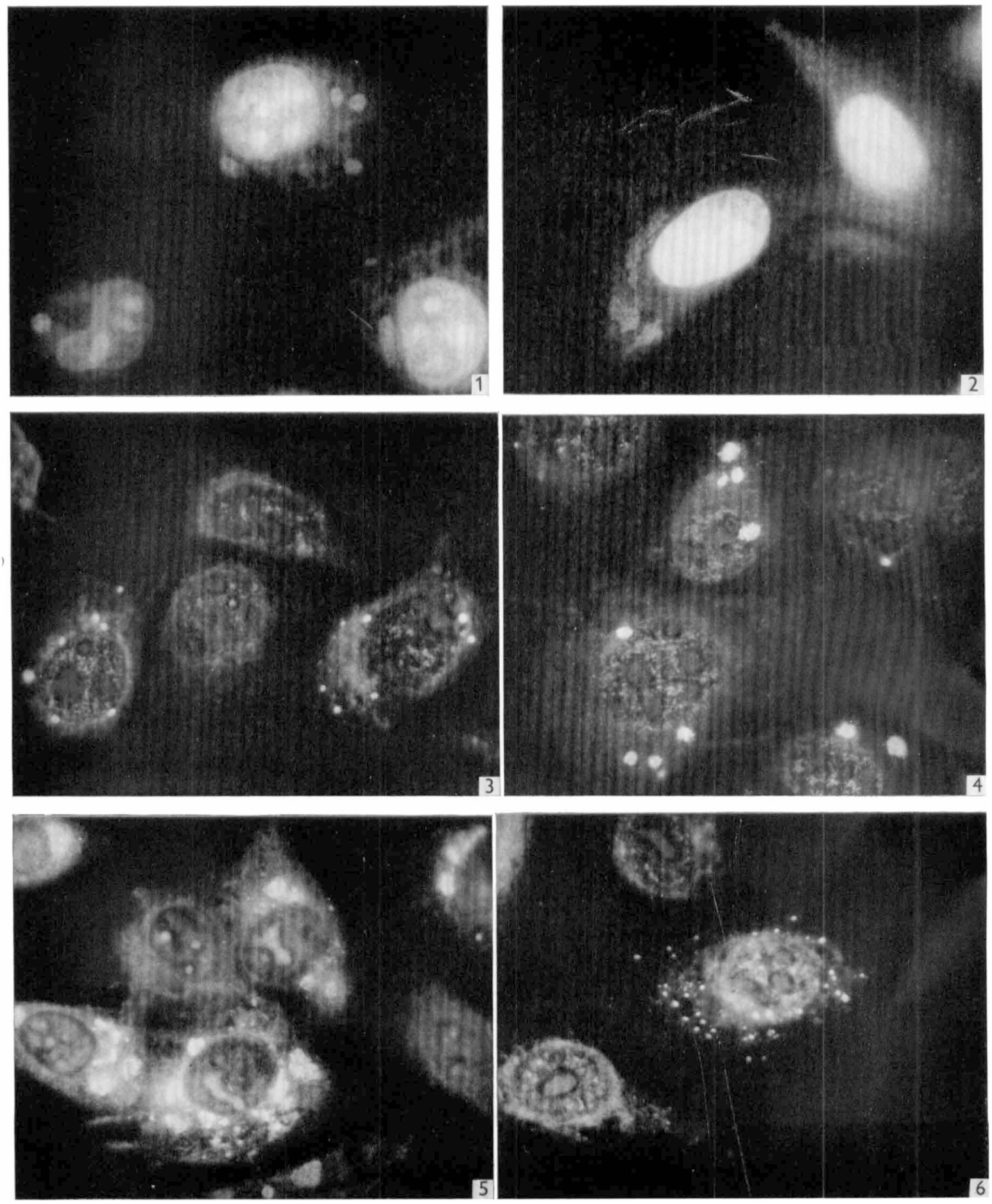

G. APPLEYARD AND J. C. N. WESTWOOD 


\section{EXPLANATION OF PLATE}

\section{Plate 1}

Fig. 1. HeLa (ERK) culture $6 \mathrm{hr}$ after infection with rabbitpox virus $10^{7}$ p.f.u. $/ \mathrm{ml}$. Stained with acridine orange. The cytoplasmic foci of DNA are well localized.

Fig. 2. Same culture as in fig. 1. One cell is uninfected; the other contains DNA foci that are beginning to spread.

Fig. 3. HeLa (ERK) culture $3 \mathrm{hr}$ after infection with rabbitpox virus $10^{7}$ p.f.u. $/ \mathrm{ml}$. Stained with fluorescein-conjugated rabbitpox antiserum. Two cells each contain seven small foci of viral antigen.

Fig. 4. As fig. 3, but culture stained $5 \mathrm{hr}$ after infection. The foci of antigen are larger, but remain well localized.

Fig. 5. As fig. 3, but culture stained $8 \mathrm{hr}$ after infection. The foci of antigen are fragmenting and spreading, and are now uncountable.

Fig. 6. HeLa (ERK) cultures $2 \mathrm{hr}$ after infection with rabbitpox virus $10^{8} \mathrm{p.f.u} . / \mathrm{ml}$. Stained with fluorescein-conjugated antiserum. The cytoplasm of one cell contains about thirty minute foci of antigen. 